\title{
Assessing Students' Attitude and Intention to Use M- learning in Higher Education
}

Hajiyev $\mathbf{J}$

Chang Gung University, Taiwan

\begin{abstract}
Mobile learning (m-learning) is a key solution for education in order to improve the learning effectiveness of students. Increasing mobile penetration in the world, particularly among the young generation urges the investigation of the factors affecting $\mathrm{m}$ learning use in higher education institutions. The primary aim of this paper is to utilize general extended technology acceptance model for e-learning (GETAMEL) developed by Abdullah and Ward (2016) to examine the factors driving the undergraduate students' attitude and intention to use m-learning in Azerbaijan with the moderating effect of Technology innovativeness (TI). The study used a survey conducted across the undergraduate students in the 7 universities located in the Baku city. The survey questionnaire was used to collect valid data from 698 samples. The Structural Equation Modelling (SEM) results revealed that Experience (XP), Subjective norms (SN), Enjoyment (ENJOY), Information and communication technologies anxiety (ICTA), and Self-efficacy (SE) significantly influence Perceived Usefulness (PU), while only XP and ICTA have an impact on Perceived ease of use (PEOU). It did not affect PU of m-learning. TI was found to have moderating effect on the relationship of PEOU and PU with Attitude (ATT), but not the relationship of ATT with Intention (INT). This study filled the gap in the $\mathrm{m}$ learning literature in Azerbaijan, and provided significant implication for both academic and government institutions willing to increase the penetration of ICT technologies and m-learning in higher education.
\end{abstract}

Key words: M-learning, GETAMEL, higher education, Azerbaijan

Published Date: March 2018

Published Online: $31^{\text {st }}$ March 2018

\section{Introduction}

By reviewing 107 e-learning adoption studies, Abdullah and Ward (2016) proposed GETAMEL, in which the authors combined the most prevalent external variables with PEOU and PU of Technology acceptance model (TAM), namely SE, SN, ENJOY, CA (replaced with ICTA), and XP. Abdullah and Ward (2016) considered SN and Social Influence (SI) as similar factors due to the fact that both of them highlight the influence of social factors on technology usage (Venkatesh et al., 2003). However, CA was replaced with ICTA due to the fact that $\mathrm{CA}$ covers the anxiety regarding the use of computers in a learning process. It is described as "the tendency of an individual to be uneasy, apprehensive, or fearful about the current or future use of computers in general" (Igbaria \& Parasuraman, 1989 , p. 375). Hence, it is considered as a crucial part of studies on e-learning adoption (Alenezi et al., 2010). ICTA and its impact on m-learning, compared to ICT use in general, was not extensively studied (Wang, 2007). In spite of a wide adoption of mobile devices and an increasing rate of Internet penetration across the country, there is no study exploring the attitude and adoption intention of m-learning among Azerbaijani undergraduate students. M-learning refers to a learning via the use of small computing devices, including smart phones and portable handheld devices (Mcconatha, Praul, \& Lynch, 2008). Based on the GETAMEL, this study fills this gap in the literature by adding external variables validated in the study of $\mathrm{Ab}$ dullah and Ward (2016) in order to examine undergraduate students' ATT and INT toward using mobile devices for educational purposes. Based on former studies in the context of consumer behavior, technology usage among the students, e-book acceptance of undergraduate students, and m-learning in higher education, we included TI as moderating variable in order to examine whether the TI level can alter the acceptance of undergraduate students toward m-learning (Nysveen, Pedersen, \& Thorjornsen, 2005; Raman, 2011; Ngafeeson \& Sun, 2015).

By considering that Azerbaijan is in the early stages of ICT and mobile technology penetration in the society and educational institutions, our approach will provide significant insight for decision makers of higher edu- 
cational institutions as well as government organizations such as the Ministry of Education to take actions for m-learning adoption and create sustainable infrastructure for it, which can facilitate learning process and motivate the active inclusion of all students in the interactive learning process. Without investigating the factors creating positive attitude and undergraduate students' intention to adopt m-learning, it would be difficult to deploy the m-learning environment and infrastructure at the universities.

The rest of the paper is organized as follows. Section 2 provides theoretical framework by initially reviewing technology acceptance model, its relationship with learning technologies and external variables that affect the attitude and intention to use m-learning, then proposing hypotheses between external variables and $\mathrm{m}$ learning system use. Section 3 presents methodology with the inclusion of data collection and study measures. Section 4 demonstrates the testing of measurement and structural model and identifies significant relationship. Finally, discussion and conclusion are given in Sections 5 and 6 respectively

\section{Theoretical framework}

\subsection{General extended technology acceptance model for e-learning}

The TAM has been widely used to identify the factors affecting learners' decision to use a new learning system. The major purpose of TAM is to explain individual's behavior towards a technology adoption, and central variables are PEOU, PU that are affected by external variables. According to Alsabawy et al. (2016), PU is a vital factor in assessing the acceptance and success of an e-learning system due to the lack of evidence on the effect of IT infrastructure on usefulness of a system. ATT influences INT towards the technology, which in turn affects actual use. As an extension of TAM model, Abdullah and Ward (2016) developed the GETAMEL. With a meta-analysis based on 107 former researches on the use of extended TAM in different e-learning adoption settings, the authors proposed GETAMEL. Their study discovered that among 152 external variables, SE, SN, ENJOY, CA and XP were the most extensively used external variables of TAM. The GETAMEL is based on these five factors. The SE is a "belief in one's capabilities to organize and execute the courses of action required to produce given attainments" (Bandura, 1997), while $\mathrm{SN}$ is referred to as "a person's perception that most people who are important to him think he should or should not perform the behavior in question" Fishbein and Ajzen (1975, p. 302). Park, Son, and Kim
(2012, p.379) defined ENJOY as "the extent to which the activity of using a specific system is perceived to be enjoyable in its own right, aside from any performance consequences resulting from system use." Venkatesh et al. (2003, p. 432) characterized CA as "evoking anxious or emotional reactions when it comes to performing a behavior." XP refers the extent to which individuals with more experience in computer use, Internet and email, as well as saving and locating files are more likely to have favorable feelings towards the e-learning system's usefulness and ease of use (Lee et al., 2013; Purnomo \& Lee, 2013). Finally, TI has been defined as the personal willingness for trying new information technologies (Agrawal \& Prasad, 1998). This study intends to employ and empirically tests the GETAMEL in m-learning domain, by examining the influence of those five external variables on students' PEOU and PU of m-learning, and determines how students' attitudes may influence their adoption intention on m-learning use for educational purposes.

\subsection{Hypothesis development}

The GETAMEL framework has been employed to test the relationships between external variables of TAM with the inclusion of PEOU, PU, ATT and INT for adoption (Abdullah \& Ward, 2016). Another study used the same external variables of TAM to investigate their influence on PEOU and PU of e-portfolios (Abdullah et al., 2016). The authors excluded the variable of "Attitude" from TAM due to the findings from previous studies that there is a weak association of PU with ATT, but a strong connection with INT (Davis et al., 1989, p. 997), and weak relationship of ATT with INT (Venkatesh et al., 2003, p. 461). However, in other studies PEOU and PU are found to be critical elements affecting the level of user attitude (Davis, 1985, 1989; Davis et al., 1989). Furthermore, Liu (2010, p. 54) stated that eliminating the variable of "Attitude" from TAM could produce better perception on the influence of PEOU and PU on "Behavioral intention" variable.

Nevertheless, in a country in which technological innovations, mobile technologies are newly introduced in different sectors such as government, education, social services, it is very important to perceive how students think about mobile technology usage for their educational mission. Without knowing their attitudes towards deployment of new technologies in education system, the study would create non-productive outcomes. Therefore, in this study, it is important to know students' attitudes firstly and then examine how 
their ATT will affect INT. For this purpose, the recent study preserves the variable in model testing as it has originally been proposed by Abdullah and Ward (2016) (shown in Fig. 1). The proposed relationships between study variables are presented further.

Fig. 1 Conceptual Model Based on GETAMEL with 5 Most Commonly Used External Variables

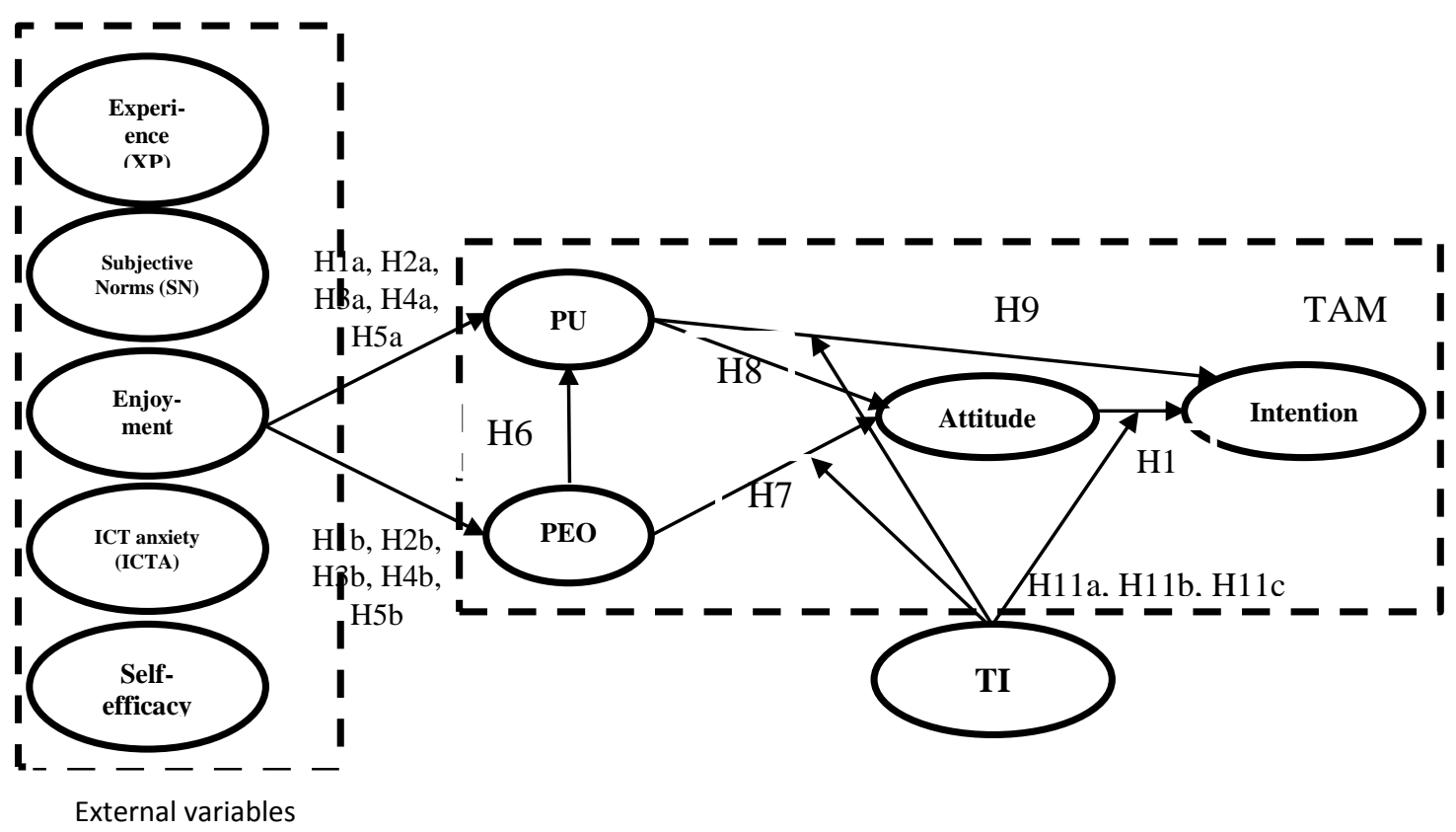

The literature related to e-learning acceptance confirmed that experience affects learners' PEOU (De Smet et al., 2012; Lee et al., 2011) and PU (Martin, 2012; Rezaei et al., 2008) on e-learning. XP also impacts the INT towards using different e-learning systems (Premchaiswadi et al., 2012; De Smet et al., 2012; Williams \& Williams, 2009). The outcomes of several studies showed that $\mathrm{SN}$ is a significant determinant of e-learning systems' acceptance by students (AlGahtani, 2016; Park, 2009). The idea of enjoyment is in agreement with inner motivation (Ryan \& Deci, 2000). ENJOY increases students' INT to use e-learning (e.g. Cheng, 2012; Yang \& Lin, 2011). ICTA has been found to have a significant influence on ICT use (Parayitam et al., 2010; Beckers, Wicherts, \& Schmidt, 2007; Imhof et al., 2007; Saadé \& Kira, 2007; Smith \& Caputi, 2007; Agarwal et al., 2000). A vast majority of researches indicated that computer anxiety would negatively affect adoption of ICT by educators in teaching process. SE is related not to the number of skills learner has, but to what learners' belief that they can do with what they have under a variety of circumstances or situation (Bandura, 1997; Rogers et al., 2008). The previous studies identified SE to be positively determined by motivation, effectiveness, and positive attitudes (Bandura, 1986).

In original TAM, there are casual relationships among user perceptual, attitudinal, and behavioral factors. (Davis, 1985, 1989; Davis et al., 1989). INT is predict- ed by PU and ATT in the TAM. The attitudes on mobile chat service use are formed by beliefs on the outcomes of using the appropriate service, and evaluation of the favorability of the outcomes (Nysveen et al., 2005). TI has been identified as a trait (Midgley \& Dowling, 1987). It is considered as a stable attribute of individuals, not related to situational considerations. In relationship with the existence of TI in technology use, Agarwal and Prasad (1998) implied that this happens through TI's association with beliefs. While concurring with Midgley and Dowling (1987) that the trait-behavior model inadequately represents the technology adoption behavior, they proposed TI as a moderator between antecedents and the consequence of perceptions in technology use. Based on the above discussion, we present the following hypotheses:

H1a, b. XP will have significant influence on PU and PEOU

H2a, b. SN will have significant influence on PU and PEOU

H3a, b. ENJOY will have significant influence on PU and PEOU

H4a, b. ICTA anxiety will have significant influence on PU and PEOU

H5a, b. SE will have significant influence on PU and PEOU

H6. PEOU will have significant influence on PU

H7. PEOU will have significant influence on ATT 
H8. PU will have significant influence on ATT

H9. PU will have significant influence on INT

H10. Attitude will have significant influence on INT

H11a, b. TI will moderate the relationship of PU and PEOU with ATT

H11c. TI will moderate the relationship of ATT with INT

\section{Methodology}

\subsection{Data collection}

A questionnaire was designed to collect data and to test the proposed model. The data collection process took 44 days (from $4^{\text {th }}$ of March to $16^{\text {th }}$ of April, 2017) in eight leading universities, namely Baku State University, Qafqaz University, Azerbaijan Technical University, Azerbaijan State University of Economics, Azerbaijan University of Architecture and Construction, Azerbaijan Tourism Institute, Azerbaijan University, and Khazar University located in Baku city. A total of 698 valid responses were obtained from 725 participants with the rate of $96.3 \% .27$ answers were removed due to the fact that they were not properly completed. Demographic analysis of respondents shows that 401 $(57.4 \%)$ of undergraduate students are males, while 297 $(42.6 \%)$ of them are females (shown in Table 1).

\subsection{Measures}

The study variables were assessed with five-point Likert scale from strongly disagree (1) to strongly agree (5) due to the fact that Likert scales are broadly used in technology acceptance domain (Abdullah et al., 2016; Park et al., 2012). The variables, namely PU, PEOU, ATT and INT and their items were adapted from the extended TAM used by Huang et al. (2007) in the context of m-learning. The external variables and their items were adapted from Abdullah et al. (2016). Moderating variable - TI and its items were adapted from Ngafeeson and Sun (2015).

Table 1 Demographic Profile of Undergraduate Students

\begin{tabular}{lcl}
\hline $\begin{array}{l}\text { Demographic } \\
(\mathrm{N}=698)\end{array}$ & profile & \\
\hline Gender & Frequency & Percentage (\%) \\
Male & & \\
Female & 401 & 57.4 \\
& 297 & 42.6
\end{tabular}

Age

18-21 years old

486

69.6

$\begin{array}{lll}22-25 \text { years old } & 195 & 27.9 \\ 26+\text { years old } & 17 & 2.4\end{array}$

Year of study

$\begin{array}{lll}\text { Year } 1 & 382 & 54.7\end{array}$

$\begin{array}{lll}\text { Year } 2 & 139 & 19.9\end{array}$

$\begin{array}{lll}\text { Year } 3 & 106 & 15.2\end{array}$

$\begin{array}{lll}\text { Final year } & 71 & 10.2\end{array}$

\begin{tabular}{lll}
$\begin{array}{l}\text { Experience in } \\
\text { mobile devices }\end{array}$ & using & \\
Less than 1 year & 19 & 2.7 \\
1 to 3 years & 179 & 25.6 \\
3 to 6 years & 336 & 48.1 \\
More than 6 years & 164 & 23.5 \\
\hline
\end{tabular}

\section{Analysis and results}

This research used the quantitative method for the purpose of analysis due to the fact that it is efficient method to draw conclusion with the techniques emphasizing reliability and validity. Furthermore, descriptive statistics of this study was examined using SPSS 22. The data analysis also included the assessment of reliability and validity. For that purpose, Structural Equation Modelling (SEM) technique was used to test validity and proposed hypotheses of the conceptual model. SEM with AMOS statistical package was used because of its appropriateness for testing multiple dependent relationships, by considering that our conceptual model has multiple independent, dependent variables as well as moderator.

\subsection{Reliability and validity}

All the variables of this research were tested with reliability, convergent validity and discriminant validity analysis. According to Hair et al. (2010), reliability test must be applied prior testing its validity. It refers to the reliability of testing the consistency between variables' multiple measurements. Reliability was tested with the composite reliability scores. CFA was performed to test the relationship between items and their respective latent variables using AMOS. In other words, CFA is to test the convergent validity and discriminant validity. The Composite Reliability (CR), and Average Variance Extracted (AVE) of all the variables exceed the acceptance level of .7 and .5 respectively, representing good internal consistency (Hair et al., 2010). Furthermore, CR values range from .791 
to .924 , and AVE values range from .533 to .798 , indicating good convergent validity. The square root of AVE for each variable must be greater than the correlation values of relationships between the variables of the measurement model. It was further discovered that square root of AVE for variable is greater than their correlation values with other variables (shown in Table 3), representing a good discriminant validity.

Table 2 Measurement Model and Convergent Validity

\begin{tabular}{|c|c|c|c|c|c|c|c|}
\hline Variables & Items & Mean & STD & Factor loading & Cronbach's $\alpha$ & $\mathrm{CR}$ & AVE \\
\hline \multirow[t]{4}{*}{$\mathrm{XP}$} & XP1 & 3.323 & 0.948 & 0.898 & 0.881 & 0.879 & 0.727 \\
\hline & XP2 & 3.059 & 0.948 & 0.923 & & & \\
\hline & XP3 & 2.978 & 0.929 & 0.893 & & & \\
\hline & XP4 & 3.146 & 0.92 & 0.352 & & & \\
\hline \multirow[t]{2}{*}{ SN } & SN1 & 2.975 & 0.93 & 0.86 & 0.864 & 0.784 & 0.798 \\
\hline & $\mathrm{SN} 2$ & 2.856 & 0.922 & 0.897 & & & \\
\hline \multirow[t]{3}{*}{ ENJOY } & ENJOY1 & 2.674 & 1.04 & 0.898 & 0.887 & 0.917 & 0.634 \\
\hline & ENJOY2 & 3.113 & 1.098 & 0.817 & & & \\
\hline & ENJOY3 & 3.005 & 0.917 & 0.903 & & & \\
\hline \multirow[t]{4}{*}{ ICTA } & ICTA1 & 1.848 & 0.968 & 0.944 & 0.91 & 0.924 & 0.672 \\
\hline & ICTA2 & 1.336 & 1.103 & 0.926 & & & \\
\hline & ICTA3 & 1.959 & 1.122 & 0.929 & & & \\
\hline & ICTA4 & 1.236 & 1.08 & 0.933 & & & \\
\hline \multirow[t]{3}{*}{ SE } & SE1 & 3.442 & 1.023 & 0.933 & 0.893 & 0.791 & 0.711 \\
\hline & SE2 & 3.157 & 1.213 & 0.889 & & & \\
\hline & SE3 & 2.954 & 1.386 & 0.876 & & & \\
\hline \multirow[t]{3}{*}{$\mathrm{PU}$} & PU1 & 2.784 & 1.362 & 0.914 & 0.905 & 0.846 & 0.683 \\
\hline & PU2 & 2.667 & 1.334 & 0.907 & & & \\
\hline & PU3 & 3.053 & 1.229 & 0.933 & & & \\
\hline \multirow[t]{3}{*}{ PEOU } & PEOU1 & 3.04 & 1.306 & 0.903 & 0.876 & 0.92 & 0.713 \\
\hline & PEOU2 & 2.855 & 0.876 & 0.882 & & & \\
\hline & PEOU3 & 2.394 & 1.051 & 0.89 & & & \\
\hline \multirow[t]{3}{*}{ ATT } & ATT1 & 2.906 & 1.062 & 0.898 & 0.854 & 0.901 & 0.733 \\
\hline & ATT2 & 2.731 & 0.974 & 0.913 & & & \\
\hline & ATT3 & 2.999 & 1.057 & 0.888 & & & \\
\hline \multirow[t]{3}{*}{ INT } & INT1 & 3.051 & 0.995 & 0.883 & 0.768 & 0.893 & 0.531 \\
\hline & INT2 & 2.592 & 0.88 & 0.461 & & & \\
\hline & INT3 & 2.841 & 0.886 & 0.885 & & & \\
\hline \multirow[t]{3}{*}{ TI } & TI1 & 2.941 & 0.977 & 0.918 & 0.853 & 0.904 & 0.678 \\
\hline & TI2 & 2.905 & 0.979 & 0.897 & & & \\
\hline & TI3 & 3.016 & 0.864 & 0.882 & & & \\
\hline
\end{tabular}


Table 3 Correlation Matrix and Discriminant Validity

\begin{tabular}{ccccccccccr}
\hline Variables & XP & SN & ENJOY & ICTA & SE & PU & PEOU & ATT & INT & TI \\
\hline XP & $\mathbf{0 . 8 5 3}$ & & & & & & & & & \\
SN & 0.409 & $\mathbf{0 . 8 9 3}$ & & & & & & & & \\
ENJOY & 0.193 & 0.433 & $\mathbf{0 . 7 9 6}$ & & & & & & & \\
ICTA & -0.049 & 0.232 & 0.302 & $\mathbf{0 . 8 2}$ & & & & & & \\
SE & 0.335 & 0.377 & 0.351 & 0.487 & $\mathbf{0 . 8 4 3}$ & & & & & \\
PU & 0.323 & 0.387 & 0.327 & 0.067 & 0.681 & $\mathbf{0 . 8 2 6}$ & & & & \\
PEOU & 0.372 & 0.352 & 0.287 & 0.034 & 0.54 & 0.671 & $\mathbf{0 . 8 4 4}$ & & & \\
ATT & 0.301 & 0.387 & 0.375 & 0.125 & 0.461 & 0.668 & 0.803 & $\mathbf{0 . 8 5 6}$ & & \\
INT & 0.376 & 0.401 & 0.367 & 0.094 & 0.382 & 0.421 & 0.114 & 0.417 & $\mathbf{0 . 7 2 9}$ & \\
TI & 0.295 & -0.071 & 0.119 & 0.051 & 0.291 & 0.045 & 0.091 & 0.273 & 0.339 & $\mathbf{0 . 8 2 3}$ \\
\hline
\end{tabular}

NOTE: Diagonal values show the square root of AVE

\subsection{Structural model}

The structural model of this study was examined using AMOS. Table 4 demonstrates the outcomes of the structural equation model. The hypotheses $(\mathrm{H} 1 \sim \mathrm{H} 11)$ in the conceptual model were tested for the sample. The first-fit index for the structural model indicated an acceptable fit $\left(\mathrm{x}^{2}=726.134 ; \mathrm{df}=538 ; \mathrm{p}\right.$ value $=.000, \mathrm{NFI}$ $=0.871 ; \mathrm{RMSEA}=0.046 ; \mathrm{CFI}=.937 ; \mathrm{GFI}=0.868$; TLI $=0.911)$. Among the $11(\mathrm{a}, \mathrm{b})$ hypotheses, 4 of them were not supported (SN to PEOU; ENJOY to PEOU; SE to PEOU; PEOU to PU. Figure 2 describes the results of the structural model test.

Table 4 Goodness-of-fit Statistics

\begin{tabular}{|c|c|c|c|}
\hline \multicolumn{2}{|l|}{ Goodness of fit } & \multirow{2}{*}{$\begin{array}{l}\text { Acceptable } \\
\text { fit }\end{array}$} & \multirow{2}{*}{$\begin{array}{r}\text { Struc- } \\
\text { tural model }\end{array}$} \\
\hline index & Good fit & & \\
\hline $\mathrm{X}^{2}$ (chi-square) & & & 726.134 \\
\hline $\begin{array}{l}\text { df (degree of } \\
\text { freedom) }\end{array}$ & & & 538 \\
\hline $\mathrm{X}^{2} / \mathrm{df}$ & $<2$ & $2.0-5.0$ & 1.3497 \\
\hline Probability & 0 & 0.05 & 0 \\
\hline NFI & $>.90$ & $.85-.90$ & 0.871 \\
\hline CFI & $>.90$ & $.85-.90$ & 0.937 \\
\hline GFI & $>.90$ & $.85-.90$ & 0.868 \\
\hline TLI & $>.90$ & $.85-.90$ & 0.911 \\
\hline RMSEA & $<.06$ & $.06-.08$ & 0.046 \\
\hline
\end{tabular}

Fig. 2 Structural Model

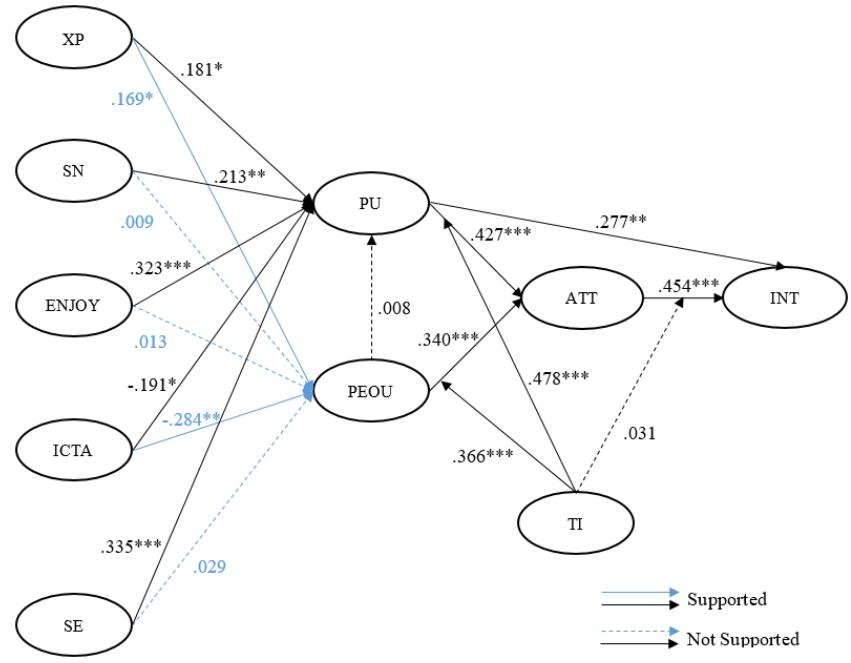

Table 6 Results of Moderation Analysis

\begin{tabular}{|c|c|c|c|c|}
\hline Step Path & Predicto & Moderator & Outco & $\beta$ values \\
\hline & & & & .340 \\
\hline Step $1 \mathrm{a}$ & PEOU & - & ATT & $* * *$ \\
\hline & & & & .427 \\
\hline Step $2 \mathrm{~b}$ & PU & - & ATT & $* * *$ \\
\hline Step $3 \mathrm{c}$ & TI & - & ATT & $.254 * *$ \\
\hline & PEOU & * & & .366 \\
\hline Step $4 \mathrm{~d}$ & TI & Yes & ATT & $* * *$ \\
\hline Step $5 \mathrm{e}$ & $\mathrm{PU} * \mathrm{TI}$ & Yes & ATT & $\begin{array}{l}.478 \\
* * *\end{array}$ \\
\hline Step 6f & ATT & - & INT & $\begin{array}{l}.454 \\
* * *\end{array}$ \\
\hline Step $7 \mathrm{~g}$ & $\mathrm{TI}$ & - & INT & $.231 * *$ \\
\hline & ATT & $*$ & & \\
\hline Step $8 \mathrm{~h}$ & TI & No & INT & 0.031 \\
\hline
\end{tabular}




\section{Discussion}

This study validated GETAMEL in terms of m-learning use of undergraduate students in the leading Azerbaijan universities for their educational purposes. It was revealed that the external variables proposed by Abdullah and $\operatorname{Ward}^{[1]}$ with the review of 107 papers related to elearning adoption predicts TAM factors of PEOU and PU differently. Hence, all of the external variables (XP, SN, ENJOY, ICTA, and SE) have significant relationship with PU, while only XP and ICTA significantly predict the students' perception on PEOU. Thus, H1a, $b$, $\mathrm{H} 2 \mathrm{~b}, \mathrm{H} 3 \mathrm{~b}, \mathrm{H} 4 \mathrm{a}, \mathrm{b}$, and $\mathrm{H} 5 \mathrm{~b}$ are supported, while $\mathrm{H} 2 \mathrm{a}$, $\mathrm{H} 3 \mathrm{a}$, and $\mathrm{H} 5 \mathrm{a}$ were rejected. It was also discovered that there is no significant influence of PU on PEOU (H6), which is against the finding of Abdullah et al. (2016) and Khanh and Gim (2014). The results show that students' perception on usefulness is more vital than their perception on ease of use in affecting their attitude to use m-learning (Huang et al., 2007). The relationship between ENJOY and PU shows that if students enjoy using m-learning system, they would find it to be useful, which is not in agreement with the finding of Huang et al. (2007). This research suggests that PU is important to determine the attitude toward use of m-learning for educational purpose (H9). This finding is similar to that of Davis, who assumed that PU is one of the central factors predicting user's attitude (Davis, 1989; Davis et al., 1989), as well as the findings of Zhu et al. (2012) in terms of m-learning in higher education in universities in China. The authors had also indicated that PU exerts more impact on user's attitude than PEOU does. Compared to Khanh and Gim (2014), this study found positive and significant relationship between PEOU and ATT (H7). This study had proposed TI to be moderator in the relationships of PEOU and PU with ATT (H11a, b). It was found that TI of the students increases the influence of PEOU and PU on ATT towards m-learning, which is not in agreement with the findings of Ngafeeson and Sun (2015). It implies that innovativeness level of the students will lead to higher perceptions of the usefulness and ease of use of the new technology. Therefore, educational institutions as well as government organizations will need to put more efforts on introducing new technologies and motivate the the young generation to get familiar with these technologies before the deployment of m-learning in the education system. Among all the latent variables, the mean value of technology innovativeness is considered to be satisfying $(\mathrm{TI}=2.941)$ following SE, XP, INT, PEOU, and SN.

\section{Conclusion}

This study verified that GETAMEL can be utilized to explain and predict the attitude of the undergraduate students to use m-learning as an educational tool to facilitate their learning process and increase the efficiency. Furthermore, positive attitudes towards mlearning also increases the possibility of the adoption intention of this learning type in the universities. As we had discussed above regarding the academic and practical implications of this research, it was revealed that external variables identified by Abdullah and Ward ${ }^{[1]}$, and employed by Abdullah et al. (2016) in elearning, also applies in m-learning context. Hence, XP, SN, ENJOY, ICTA and SE are more significant determinants of PU compared to the PEOU. Thus, educational institutions must concentrate on promoting the usefulness of m-learning. In addition, PU affects ATT more than PEOU, showing that usefulness of m-learning is central for the students. Higher ICTA leads to negative ATT toward the usefulness and ease of use of the m-learning. Therefore, educational institutions and government bodies must try to reduce the anxiety of using new technologies among the young generation. Furthermore, innovativeness must be increased in order to create more positive ATT towards using m-learning. Increasing Internet penetration rate and mobile device usage among the young generation clearly shows that students are familiar with new technologies and willing to use them in their educational pursuits. Our findings can be a guide in planning the m-learning strategy across the leading universities in Azerbaijan.

\section{References}

[1] Abdullah, F., \& Ward, R. (2016). Developing a General Extended Technology Acceptance Model for E-Learning (GETAMEL) by analysing commonly used external variables. Computers in Human Behavior, 56, 238-256.

[2] Venkatesh, V., Morris, M. G., Davis, G. B., \& Davis, F. D. (2003). User acceptance of information technology: toward a unified view. MIS Quarterly, 27(3), 425-478.

[3] Alenezi, A. R., Abdul Karim, A. M., \& Veloo, A. (2010). An empirical investigation into the role of enjoyment, computer anxiety, computer self-efficacy and internet experience in influencing the students' intention to use e-learning: a case study from Saudi Arabian Governmental Universities. The Turkish Online Journal of Educational Technology, 9(4), 2234.

[4] Wang, Y.-S. (2007). Development and validation of a mobile computer anxiety scale. British Journal of 
Educational Technology, 38(6), 990-1009. http://dx.doi.org/10.1111/j.1467-8535.2006.00687.x.

Retried on 15.02.2017

[5] Mcconatha, D., Praul, M., \& Lynch, M. J. (2008). Mobile learning in higher education: An empirical assessment of a new educational tool. Online Submission, 7(3).

[6] Alsabawy, A. Y., Cater-Steel, A., \& Soar, J. (2016). Determinants of perceived usefulness of e-learning systems. Computers in Human Behavior, 64, 843-858.

[7] Alzaza, N. S., \& Yaakub, A. R. (2011). Students' awareness and requirements of m-learning services in the higher education environment. American Journal of Economics and Business Administration, 3(1), 95.

[8] Al-Gahtani, S. S. (2014). Empirical investigation of e-learning acceptance and assimilation: a structural equation model. Applied Computing and Informatics. http://dx.doi.org/10.1016/j.aci.2014.09.001. Retried on 12.02.2017

[9] Bandura, A. (1997). Self- efficacy: The exercise of control. United States of America: W.H. Freeman and Company.

[10] Bandura, A. (1986). Social foundations of thought and action: A social cognitive theory. Englewood Cliffs, NJ: Prentice-Hall.

[11] Beckers, J. J., Wicherts, J. M., \& Schmidt, H. G. (2007). Computer anxiety: "Trait" or "state"? Computers in Human Behavior, 23(6), 2851-2862. http://dx.doi.org/10.1016/j.chb.2006.06.001. Retried on 12.02.2017

[12] Cheng, Y. (2012). Effects of quality antecedents on e-learning acceptance. Internet Research, 22(3), 361390. Retrieved from https://library3.hud.ac.uk/summon/. Retried on 14.02.2017

[13] Chu, H.-C., Hwang, G.-J., Huang, S.-X., \& Wu, T.-T. (2008). A knowledge engineering approach to developing e-libraries for m-learning. The Electronic Library, 26(3), 303-317. http://dx.doi.org/10.1108/ 02640470810879464. Retried on 18.02.2017

[14] Davis, F. D. (1989). Perceived usefulness, perceived ease of use and user acceptance of information technology. MIS Quarterly, 13, 319-339.

[15] Davis, F. D. (1986). A technology acceptance model for empirically testing new end user information systems: Theory and result. Doctoral dissertation (pp. 1-291). Sloan School of Management. Massachusetts Institute of Technology. Retrieved from: http://dspac e.mit.edu/handle/1721.1/15192. Retried on 23.02.2017

[16] Davis, F. (1985). A technology acceptance model for empirically testing new end-user information systems: theory and results. Unpublished Doctoral dissertation, MIT Sloan School of Management, Cambridge, MA.
[17] Fishbein, J., \& Ajzen, I. (1975). Belief, attitude, intention, and behavior: An introduction to theory and research. Reading, MA: Addison-Wesley.

[18] Hair, J. F., Anderson. R. E., Black. W.C., \& Babin. B.J. (2010). Multivariate Data Analysis, seventh ed., Pearson Prentice Hall, Upper Saddle River, New Jersey, NJ.

[19] Hair, J., Black, W., Babin, B., Anderson, R., \& Tatham, R. (2006). Multivariate data analysis (6th ed.). Uppersaddle River, N.J.: Pearson Prentice Hall.

[20] Khanh, N. T. V., \& Gim, G. (2014). Factors influencing mobile-learning adoption intention: An empirical investigation in high education. Journal of Social Sciences, 10(2), 51-62.

[21] Lee, Y., Hsieh, Y., \& Chen, Y. (2013). An investigation of employees' use of e-learning systems: applying the technology acceptance model. Behaviour and Information Technology, 32(2), 173-189. Retrieved from: https://library3.hud.ac.uk/summon/. Retried on 15.02.2017

[23] Ngafeeson, M.N., \& Sun, J. (2015). The effects of technology innovativeness and system exposure on student acceptance of e-textbooks. Journal of Information Technology Education: Research, 14, 55-71.

[25] Park, Y., Son, H., \& Kim, C. (2012). Investigating the determinants of construction professionals' acceptance of web-based training: an extension of the technology acceptance model. Automation in Construction, 22, 377-386. Retrieved from: https://libra ry3.hud.ac.uk/summon/. Retried on 15.02.2017

[26] Purnomo, S. H., \& Lee, Y. (2013). E-learning adoption in the banking workplace in Indonesia: an empirical study. Information Development, 29(2), 138-153.

http://dx.doi.org/10.1177/0266666912448258. Retried on 18.02.2017

[28] Venkatesh, V., \& Davis, F. D. (1996). A model of the antecedents of perceived ease of use: Development and test. Decision Science, 27(3), 451-481.

[30] Williams, M., \& Williams, J. (2009). Evaluating a model of business school students' acceptance of web-based course management systems. International Journal of Management Education, 8(3), 59-70. http://dx.doi.org/10.3794/ijme.83.264. Retried on 15.02.2017

[31] Yang, S. C., \& Lin, C. H. (2011). .Factors affecting the intention to use Facebook to support problembased learning among employees in a Taiwanese manufacturing company. African Journal of Business Management, 5(22), 9014-9022. http://dx.doi.org/ 10.5897/AJBM11.1191. Retried on 23.02.2017

[32] Zhu, Q., Guo, W., \& Hu, Y. (2012). M-learning in higher education. Students' acceptance of $\mathrm{m}$ - 
learning in three top Chinese universities. Bachelor's thesis within Informatics Business and IT Management Jonkoping University.

[33] Nysveen, H., Pedersen, P.E. and Thorbjornsen, H. (2005). Explaining intention to use mobile chat services: Moderating effects of gender. Journal of Consumer Marketing, 22(5), 247-256.

[34] Abdullah, F., Ward, R., \& Ahmed, E. (2016). Investigating the influence of the most commonly used external variables of TAM on students' Perceived Ease of Use (PEOU) and Perceived Usefulness (PU) of e- portfolios. Computers in Human Behavior, 63, 75-90. [35] Agarwal, R., \& Prasad, J. (1998). A conceptual and operational definition of personal innovativeness in the domain of informational technology. Information Systems Research, 9 (2), 204-215.

[36] Agarwal, R., Sambamurthy, V., \& Stair, R. M. (2000). Research report: The evolving relationship between general and specific computer self-efficacyan empirical assessment. Information Systems Research, 11(4), 418-430. http://dx.doi.org/10.1287/is re.11.4.418.11876. Retried on 12.02.2017 